\title{
Geochemistry of rare earth elements and yttrium in a Ge-poor coal from the Wulantuga ore deposit, Inner Mongolia, North China
}

\author{
Jingjing Liu $\cdot$ Yaofa Jiang $\cdot$ Panpan Xie $\cdot$ Qingqian Li
}

Received: 28 October 2014/Revised: 6 November 2014/Accepted: 11 November 2014/Published online: 11 March 2015

(C) The Author(s) 2015. This article is published with open access at Springerlink.com

\begin{abstract}
This paper reports data of yttrium and rare earth (REY, or REE if Y is considered) in a Ge-poor (the average value of Ge is $0.57 \mu \mathrm{g} / \mathrm{g}$ ) coal from the Wulantuga ore deposit, middle Inner Mongolia, northern China. The contents of yttrium and rare earth in six coal samples of the Wulantuga ore deposit were detected by inductively coupled plasma mass spectrometry. The content of yttrium and rare earth in the study area varies from 5.88 to $119.19 \mu \mathrm{g} / \mathrm{g}$, with an average of $61.85 \mu \mathrm{g} / \mathrm{g}$, similar to the average value for world coals. The light-REY and heavy-REY enrichments are the two major REY-enrichment types of the Ge-poor coal from the Wulantuga ore deposit, and the top and bottom parts of the coal seam have a higher content of REY than the middle part. The sources of yttrium and rare earth in the Ge-poor coal of Wulantuga may be mainly associated with terrigenous materials and natural waters enriched in yttrium and rare earth.
\end{abstract}

Keywords Rare earth and yttrium $\cdot$ Wulantuga $\cdot$ Distribution pattern $\cdot$ Ge-poor coal

\section{Introduction}

Rare earth elements (REE) include $\mathrm{La}, \mathrm{Ce}, \mathrm{Pr}, \mathrm{Nd}, \mathrm{Sm}, \mathrm{Eu}$, $\mathrm{Gd}, \mathrm{Tb}, \mathrm{Dy}, \mathrm{Ho}, \mathrm{Er}, \mathrm{Tm}, \mathrm{Yb}$ and $\mathrm{Lu}$, with atomic number from 57 to 71. Because of both similar geochemical characteristics and ionic radius to lanthanides, yttrium is generally considered as a rare earth element (Liu and Cao 1984).

Yttrium and rare earth can be used as geochemical indicators in coal and coal-bearing strata because they own relatively stable geochemical characteristics during different geological processes ( $\mathrm{Li}$ et al. 2005). Yttrium and rare earth may provide significant information for the study of terrigenous areas and oxidation-reduction environment of

J. Liu $(\bowtie) \cdot$ P. Xie · Q. Li

College of Geoscience and Surveying Engineering, China

University of Mining and Technology (Beijing), Beijing 100083,

China

e-mail: liujingjing125@126.com

Y. Jiang

Jiangsu Institute of Architectural Technology, Xuzhou 221116,

China peat accumulation, history of tectonic evolution, volcanic ash eruption, and hydrothermal solution activities. For instance, based on the analysis of modes of trace-element (including yttrium and rare earth) and mineral occurrence, Dai et al. (2014a) revealed the dominant sediment-source regions for the late Permian coal-bearing strata of the Huayingshan coalfield, eastern Sichuan, southwestern China, are the Dabashan and Leshan-Longnvsi Uplifts and the Hannan Upland. Moreover, the first finding of coal beds with high yttrium and rare earth elements contents in one of the coal-hosted ore deposits in Russia Far East has made the extraction of rare earth and Yttrium possible. Seredin (1996) noted that a total of several coal seams with similar and even higher contents (up to $1.0 \%$ in ash) of yttrium and rare earth were found in six coal-bearing basins of this region. Owing to the increasing significance of REY role in industry, more and more attention is focused on the yttrium and rare earth in coal and coal combustion products.

Zhang et al. (2008) and Dai et al. (2014b) reported the concentrations of yttrium and rare earth in the Ge-elevated coal $(273 \mu \mathrm{g} / \mathrm{g})$ from the Wulantuga deposit. However, data of yttrium and rare earth in the Ge-poor coal of $\mathrm{Wu}$ lantuga are absent. This paper reports the data of six Ge- 
poor coal samples from the coal-hosted Ge ore deposit from Wulantuga and thus could shed light on the yttrium and rare earth formation in the coal.

\section{Geological background}

The present study area is situated on the edge of southwestern Shengli coalfield, which was formed in the faultcontrolled Shengli sub-basin of the Erlian Basin in Inner Mongolia. The Shengli coalfield is in the Wunite depression in the west of Erlian Basin, and is located in a wide syncline (Huang et al. 2007), with a 45-km length and 7.6$\mathrm{km}$ width, and a surface area of $342 \mathrm{~km}^{2}$.

The Silurian, Devonian, Permian, Late Jurassic, Early Cretaceous, Neogene, and Quaternary are the sedimentary sequences in the Shengli coalfield (Fig. 1; Dai et al. 2012a). The Silurian and Devonian sedimentary strata have an average thickness of $2,363 \mathrm{~m}$ and are composed of various quartz schists. The minimum and maximum thickness of the Permian strata is 680 and $3,550 \mathrm{~m}$, respectively. The Permian strata are covered by sandy mudstone, conglomerate, siltstone interbeded with limestone layers, lenses of andesitic tuffs and limestones. The lower part is made up of sandstone, andesite, interlayered with andesitic tuff, bioclastic rocks, limestone, marl, volcaniclastic rocks, mudstone and rhyolite. The upper Jurassic strata have a thickness of more than $3,734 \mathrm{~m}$ and consist of mafic and intermediate-felsic volcanic rocks (e.g., basalts, tuffs, volcanic breccia, quartz trachyandesite, and rhyolite). The coal-containing lower Cretaceous strata, collectively titled "Bayanhua Group", disconformably overlie the Jurassic system. It is made up of Hadatu, Aershan, and Saihantala Formations (Sha 2007). However the Hadatu Formation is absent in the area of the present study. As previously reported, the Aershan Formation of Gecontaining part of the Shengli Coalfield, is named the Tenggeer Group (Qi et al. 2007) or Xilin Formation, and the Saihantala Formation is named the Shengli Formation. The lower part with thickness from 70 to $564 \mathrm{~m}$ of the Xilin Formation is made up of fine sandstone, conglomerate, sandstone, and gravels interlayered with thin benches of mudstone. The middle part (generally 180-200 m) of the Xilin Formation is composed of coarse sandstone, grey mudstone, siltstone, and coal beds. The upper part (132.9-466 m, generally 160-180 m) of the Xilin Formation is mainly dominated by siltstone and mudstone. The No. 11 and 12 coal seams, with average thicknesses of 1.54 and $2.30 \mathrm{~m}$ respectively, are the two major coal beds in the Xilin Formation. The Neogene strata (average thickness $49.84 \mathrm{~m}$ ) are predominantly composed of clay and gravels and disconformably overlie the Shengli Formation. It is noted that the distance between the early Cretaceous No. 6
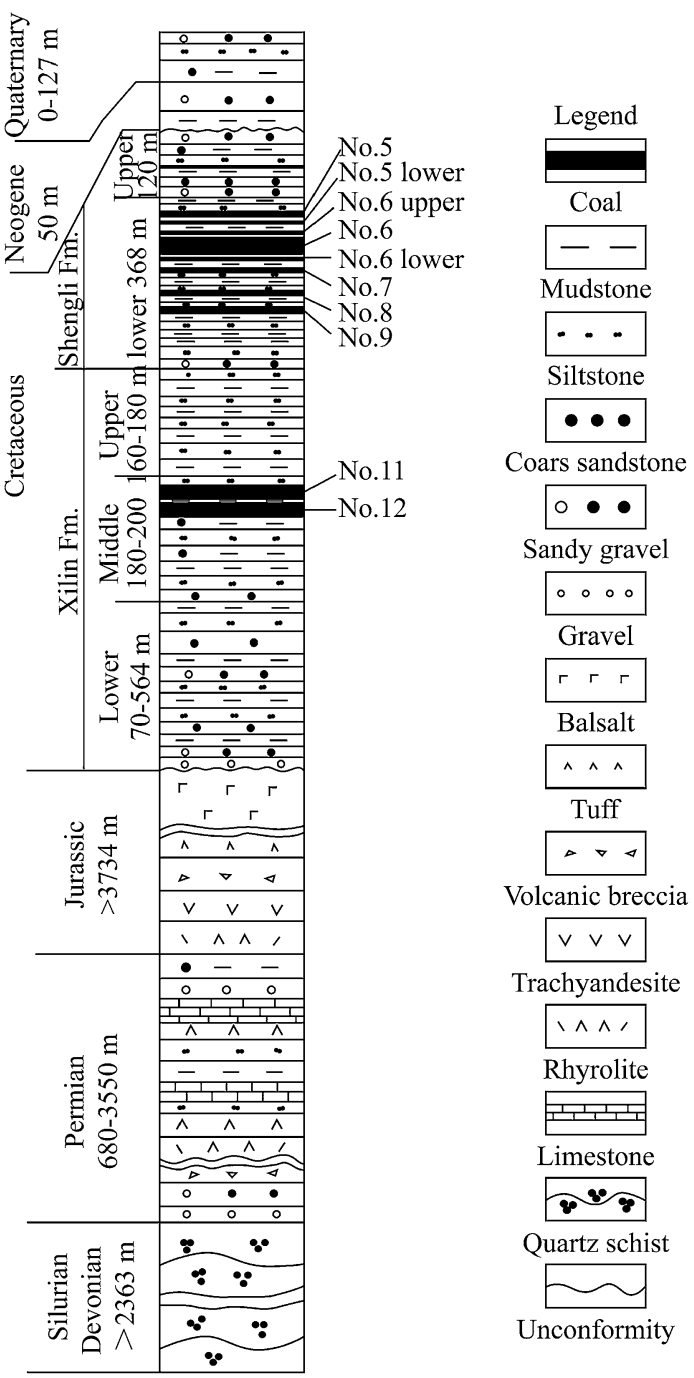

Fig. 1 Coal-containing sedimentary strata of the Wulantuga ore deposit (after Dai et al. 2012a)

coal collected in the deposit and the previously studied Gerich coal deposit is around $200 \mathrm{~m}$.

\section{Analytical procedures}

A total of 6 coal ply samples were collected from the mining face of the mined No. 6 coal, which have an average thickness of $16.1 \mathrm{~m}$ at the Wulantuga Ge-poor deposit of the Shengli Coalfield in Inner Mongolia, North China. The collection method was following the Chinese Standard Method GB/T 482-2008 (2008). From top to bottom, the 6 coal ply samples were identified as WLTG-1 to WLTG-6.

Yttrium and rare earth in the coal samples were determined by ICP/MS (X series IIICP/MS). Before 
geochemical analysis, the six coal samples were ground to less than 200 mesh and were digested using an UltraClave microwave high pressure reactor (Milestone). The mixedsolution of 330-mL distilled $\mathrm{H}_{2} \mathrm{O}, 30-\mathrm{mL} 30 \% \mathrm{H}_{2} \mathrm{O}_{2}$, and 2-mL $98 \% \mathrm{H}_{2} \mathrm{SO}_{4}$ were put into the digestion tank, served as the basic load. Initial nitrogen pressure for the wave digestion was 50 bars and the highest digestion-temperature was $240{ }^{\circ} \mathrm{C}$. Such high-pressure and high-temperature digestion process lasts for about $75 \mathrm{~min}$. The reagents for 50-mg coal sample digestion consist of $2 \mathrm{~mL}$ $40 \% \mathrm{HF}$ and $5 \mathrm{~mL} 65 \% \mathrm{HNO}_{3}$. Multi-element standards of Inorganic Ventures (CCS-1) were used for calibration of yttrium and rare earth content in tested samples as designed by Dai et al. (2011).

\section{Results and discussion}

As indicated in Table 1, the content of yttrium and rare earth in study area varies from 5.88 to $119.19 \mu \mathrm{g} / \mathrm{g}$, with an average of $61.85 \mu \mathrm{g} / \mathrm{g}$, similar to the average values for the world low-rank coals reported by Ketris and Yudovich (2009) $(68.5 \mu \mathrm{g} / \mathrm{g})$. Table 1 illustrates that the lignite in the Wulantuga ore deposit is mainly enriched in light and heavy REY, and only sample WLTG-4 is enriched in medium REY. The top and bottom parts of the coal seam have higher contents of REY than that in the lower part. The $\delta$ Eu values vary from 0.53 to 1 , with an average of 0.79 , showing a pronounced Eu minimum. The $\delta \mathrm{Ce}$ values vary from 0.75 to 0.99 (with an average of 0.92 ), indicating a slightly positive anomaly.

Content coefficients (REY content in the studied coal samples vs. world coals and Chinese coals) are presented in Fig. 2. With exceptions of $\mathrm{La}, \mathrm{Sm}$, and Er, the contents of other REY are lower than the average values for world and Chinese coals, respectively reported by Ketris and Yudovich (2009), and Dai et al. (2012b).
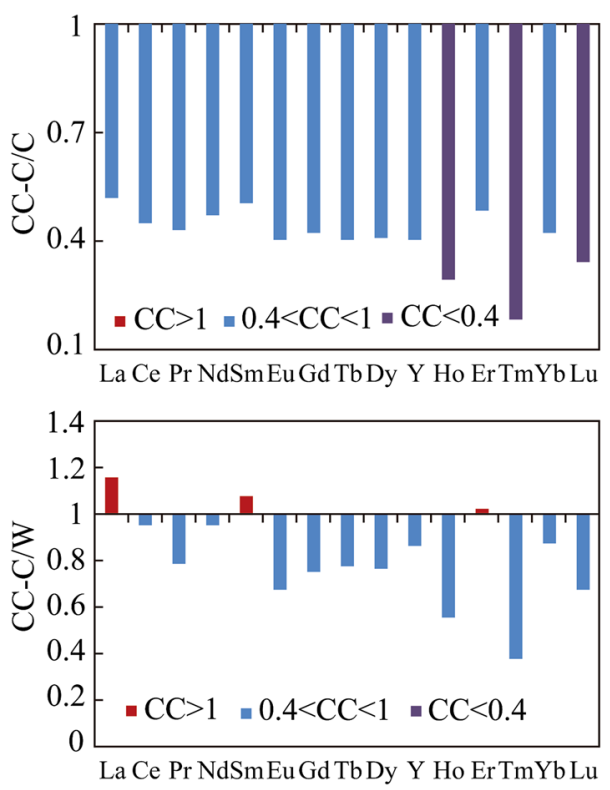

Fig. 2 Concentration coefficients of REY in Ge-poor coals of Wulantuga deposit. $\mathrm{CC}-\mathrm{C} / \mathrm{C}$, concentration coefficients of coal samples versus Chinese coals; CC-C/W, concentration coefficients of coal samples versus world coals

Rare earth elements are generally classified into two types: Light-REE (LREE: La, Ce, Pr, Nd, Sm, and Eu) and Heavy-REE (HREE: Gd, Tb, Dy, Ho, Er, Tm, Yb, and $\mathrm{Lu}$ ) (Han and Ma 2003). Compared to the two-fold classification, the three-fold geochemistry classification of REY proposed by Seredin and Dai (2012), however, is more distinct to describe the REY distribution in coals and conventional REY ore deposits. This paper used the latter classification, and accordingly, normalized the original content of REY in coal samples by the abundance of REY in the upper continental crust (UCC; Taylor and McLennan 1985). The average REY contents of Chinese

Table 1 REY in the No. 6 coal from the Wulantuga ore deposit, Inner Mongolia $(\mu \mathrm{g} / \mathrm{g})$

\begin{tabular}{|c|c|c|c|c|c|c|c|c|c|c|}
\hline Sample ID & REY & LREY & MREY & HREY & $(\mathrm{La} / \mathrm{Lu})_{\mathrm{N}}$ & $(\mathrm{La} / \mathrm{Sm})_{\mathrm{N}}$ & $(\mathrm{Gd} / \mathrm{Lu})_{\mathrm{N}}$ & Enrichment type & $\delta \mathrm{Eu}$ & $\delta \mathrm{Ce}$ \\
\hline WLTG-1 & 196.4 & 162.02 & 29.15 & 5.24 & 1.42 & 0.9 & 0.7 & $\mathrm{~L}$ & 0.7 & 0.75 \\
\hline WLTG-2 & 17.33 & 9.83 & 6.4 & 1.11 & 0.39 & 0.58 & 1 & $\mathrm{H}$ & 1 & 0.9 \\
\hline WLTG-3 & 20.65 & 14.78 & 4.8 & 1.07 & 0.52 & 0.73 & 0.9 & $\mathrm{H}$ & 0.53 & 0.94 \\
\hline WLTG-4 & 5.88 & 4.63 & 1.08 & 0.17 & 2 & 1 & 2.5 & M & 0.89 & 0.96 \\
\hline WLTG-5 & 11.64 & 8.84 & 2.4 & 0.4 & 1.17 & 0.78 & 1.83 & $\mathrm{~L}$ & 0.8 & 0.91 \\
\hline WLTG-6 & 119.19 & 87.94 & 25.53 & 5.71 & 0.58 & 0.81 & 0.88 & $\mathrm{H}$ & 0.87 & 0.99 \\
\hline Pre-wltg ${ }^{\mathrm{a}}$ & 28.53 & 20.5 & 6.88 & 1.15 & 1.23 & 0.8 & 1.85 & & 0.77 & 0.97 \\
\hline
\end{tabular}

$L R E Y$ light rare earth elements including $\mathrm{La}, \mathrm{Ce}, \mathrm{Pr}, \mathrm{Nd}$, and $\mathrm{Sm}, M R E Y$ medium rare earth elements including Eu, Gd, Tb, Dy, and Y, HREY heavy rare earth elements including Ho, Er, Tm, Yb, and Lu, REY are normalized by Upper Continental Crust reported by Taylor and McLennan (1985), $L$ light REY enrichment type, $M$ medium REY enrichment type, $H$ heavy REY enrichment type, $\delta \mathrm{Eu}^{1 / 2} \mathrm{Eu}_{\mathrm{N}} /\left(\mathrm{Sm}_{\mathrm{N}} \times \mathrm{Gd}_{\mathrm{N}}\right)^{1 / 2}$; $\delta \mathrm{Ce}=\mathrm{Ce}_{\mathrm{N}} /\left(\mathrm{La}_{\mathrm{N}} \times \mathrm{Pr}_{\mathrm{N}}\right)^{1 / 2}$

a Data from Dai et al. (2012a) 
and world coals are normalized to the UCC (Fig. 3). The distribution curves of REY averages for both Chinese and world coals are similar to those of the UCC, with exception of $\mathrm{Tm}$.

Based on the three-fold classification (Seredin and Dai 2012), three enrichment types are identified in the coal samples present in this study, including Light-type (lightREY; $\mathrm{La}_{\mathrm{N}} / \mathrm{Lu}_{\mathrm{N}}>1$ ), Medium-type(medium-REY; $\mathrm{La}_{\mathrm{N}} /$ $\mathrm{Sm}_{\mathrm{N}}<1, \mathrm{Gd}_{\mathrm{N}} / \mathrm{Lu}_{\mathrm{N}}>1$ ), and Heavy-type (heavy-REY; $\left.\mathrm{La}_{N} / \mathrm{Lu}_{\mathrm{N}}<1\right)$. The REY compositional characteristics in coal samples WLTG-1 and WLTG-5 (Fig. 4a, c) are characterized by Light-type. The Light-type compositional characteristics of REY in coals are usually caused by the input from terrigenous materials in the sediment source region during peat accumulation (Dai et al. 2012a). The LREY-type in the coals is probably attributed to the occurrence of light REY-rich magmatic rocks (granite or carbonatite) and deep weathering products from granite (Seredin and Dai 2012). The Medium-type compositional characteristics of REY in WLTG-4 (Fig. 4c), with a relatively strong pronounced Eu-minimum, are due to acid natural waters (Johanneson and Zhou 1997) and are probably derived from acid hydrothermal solutions (Seredin and Dai 2012). The Heavy-type compositional characteristics are shown in Fig. 4b, d. Because of the wide spread of HREY-enriched natural water that may circulate in coalbearing strata, the precipitated REY-enriched matter lead to the higher HREY content in the coal samples (e.g., Seredin 2001; Seredin and Dai 2012). These waters may be high-temperature $\left(>500{ }^{\circ} \mathrm{C}\right)$ volcanogenic solutions (Rybin et al. 2003), alkaline terrestrial fluids (Johanneson and Zhou 1997), low-temperature $\left(130^{\circ} \mathrm{C}\right)$ alkaline hydrothermal waters (Michard and Albarède 1986), some high $\mathrm{pCO}_{2}$ cold mineral solutions (Shand et al. 2005), and seawater (Elderfield and Greaves 1982).

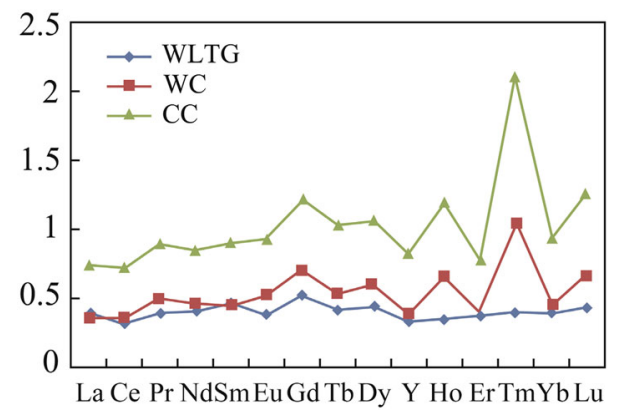

Fig. 3 REY plots for average values in Wulantuga (WLTG), Chinese coals (CC) and world coals (WC). Data of Chinese coals and world coals are from Dai et al. (2012b) and Ketris and Yudovich (2009) respectively. Normalized by average REY content of Upper Continental Crust (UCC) (Taylor and McLennan 1985)
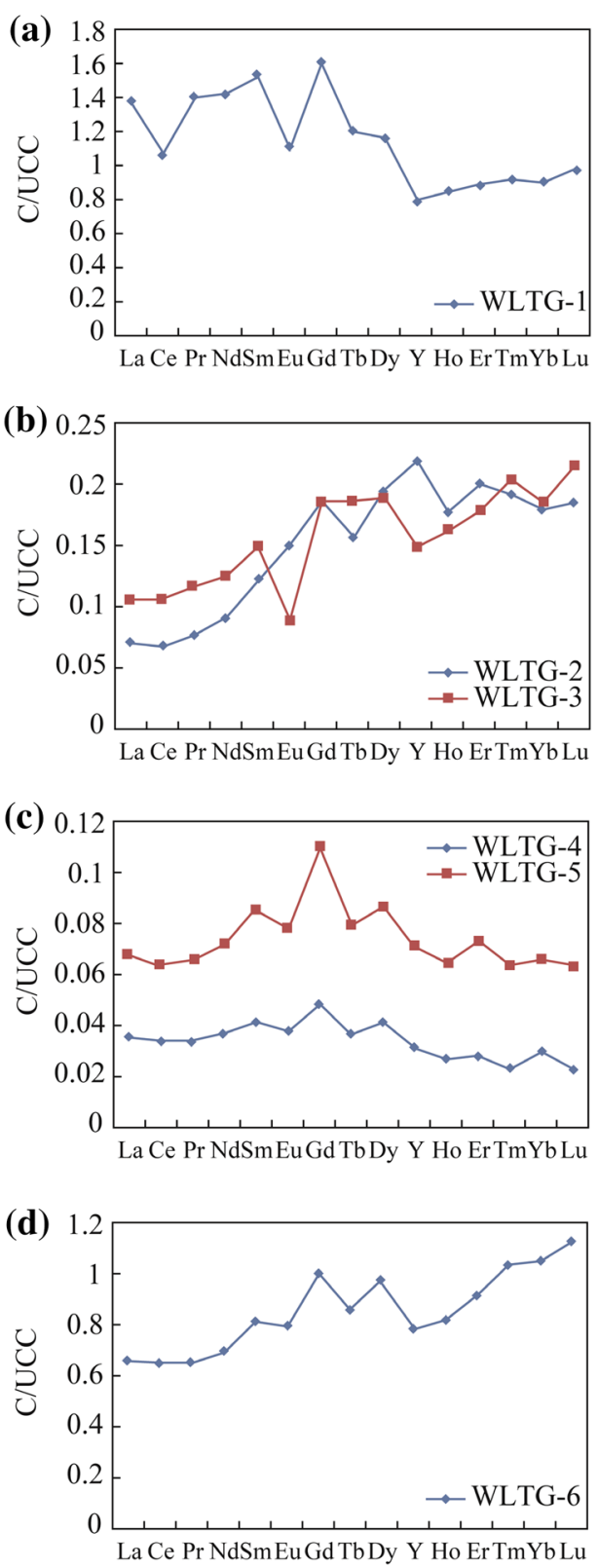

Fig. 4 REY compositional characteristics in the No. 6 coal in the Wulantuga, Inner Mongolia, China

\section{Conclusions}

(1) The concentration of REY in study area varies from 5.88 to $119.19 \mu \mathrm{g} / \mathrm{g}$, with an average content of $61.85 \mu \mathrm{g} / \mathrm{g}$, similar to the average values for world low-rank coals.

(2) The light-REY and heavy-REY are the main REYenrichment type of the Ge-poor coal from the Wulantuga ore deposit. The top and bottom parts of the coal seam have a higher content of REY than that of the middle part. 
(3) The occurrence of REY in the Ge-poor coal of Wulantuga may be associated mainly with terrigenous materials input and natural waters enriched in yttrium and rare earth.

Acknowledgments The authors are grateful to the two anonymous reviewers for their careful comments, which improved the manuscript quality.

Open Access This article is distributed under the terms of the Creative Commons Attribution License which permits any use, distribution, and reproduction in any medium, provided the original author(s) and the source are credited.

\section{References}

Chinese Standard Method GB/T 482-2008 (2008) Sampling of coal seams (in Chinese)

Dai SF, Wang XB, Zhou YP, Hower JC, Li DH, Chen WM, Zhu XW, Zou JH (2011) Chemical and mineralogical compositions of silicic, mafic, and alkali tonsteins in the late Permian coals from the Songzao Coalfield, Chongqing, Southwest China. Chem Geol 282:29-44

Dai SF, Ren DY, Chou CL, Finkelman RB, Seredin VV, Zhou YP (2012a) Geochemistry of trace elements in Chinese coals: a review of abundances, genetic types, impacts on human health, and industrial utilization. Int $\mathrm{J}$ Coal Geol 94:3-21

Dai SF, Wang XB, Seredin VV, Hower JC, Ward CR, O'Keefe JMK, Huang WH, Li T, Li X, Liu HD, Xue WF, Zhao L (2012b) Petrology, mineralogy, and geochemistry of the Ge-rich coal from the Wulantuga Ge ore deposit, Inner Mongolia, China: new data and genetic implications. Int J Coal Geol 90-91:72-99

Dai SF, Luo YB, Seredin VV, Ward CR, Hower JC, Zhao L, Liu SD, Zhao CL, Tian HM, Zou JH (2014a) Revisiting the late Permian coal from the Huayingshan, Sichuan, southwestern China: enrichment and occurrence modes of minerals and trace elements. Int J Coal Geol 122:110-128

Dai SF, Seredin VV, Ward CR, Jiang JH, Hower JC, Song XL, Jiang YF, Wang XB, Gornostaeva T, Li X, Liu HD, Zhao L, Zhao CL (2014b) Composition and modes of occurrence of minerals and elements in coal combustion products derived from high-Ge coals. Int J Coal Geol 121:79-97

Elderfield H, Greaves MJ (1982) The rare earth elements in seawater. Nature 296:214-219
Han YW, Ma ZD (2003) Geochemistry. Geology Publishing House, Beijing (in Chinese)

Huang WH, Sun L, Ma YY, Wan H, Tang XY, Du G, Wu W, Qin SL, Finkelman RB (2007) Distribution and geological feature of the Coal-Ge deposit of Shengli coalfield in Inner Mongolia of China. J China Coal Soc 32(11):1147-1151 (in Chinese with English abstract)

Johanneson KJ, Zhou XP (1997) Geochemistry of the rare earth element in natural terrestrial waters: a review of what is currently known. Chin J Geochem 16:20-42

Ketris MP, Yudovich YE (2009) Estimations of Clarkes for carbonaceous biolithes: world average for trace element contents in black shales and coals. Int J Coal Geol 78:135-148

Li DH, Tang YG, Chen K, Du T, Cheng FP, Yang J (2005) Research on geochemistry of rare earth elements in coals from Chongqing, China. J China Univ Min Technol 34:312-317 (in Chinese with English abstract)

Liu YJ, Cao LM (1984) Geochemistry of elements. Science Press, Beijing (in Chinese)

Michard A, Albarède F (1986) The REE content of some hydrothermal fluids. Chem Geol 55:51-60

Qi HW, Hu RZ, Zhang Q (2007) Concentration and distribution of trace elements in lignite from the Shengli coalfield, Inner Mongolia, China: implications on origin of the associated Wulantuga germanium deposit. Int J Coal Geol 71:129-152

Rybin AV, Gur'yanov VB, Chibisova MV, Zharkov RV (2003) Rhenium exploration prospects on Sakhalin and the Kuril Islands, geodynamics, magmatism, and minerageny of the North Pacific Ocean. Magadan 3:180-183 (in Russian)

Seredin VV (1996) Rare earth element-bearing coals from the Russian Far East deposits. Int J Coal Geol 30:101-129

Seredin VV (2001) Major regularities of the REE distribution in coal. Dokl Earth Sci 377:250-253

Seredin VV, Dai SF (2012) Coal deposits as potential alternative sources for lanthanides and yttrium. Int J Coal Geol 94:67-93

Sha JG (2007) Cretaceous stratigraphy of northeast China: nonmarine and marine correlation. Cretac Res 28:146-170

Shand P, Johannesson KH, Chudaev O, Chudaeva V, Edmunds WM (2005) Rare earth element contents of high $\mathrm{p} \mathrm{CO}_{2}$ groundwaters of Primorye, Russia: mineral stability and complexation controls. In: Johannesson $\mathrm{KH}$ (ed) Rare earth elements in groundwater flow system. Springer, Amsterdam, 161-186

Taylor SR, McLennan SM (1985) The continental crust: its composition and evolution. Blackwell, Oxford

Zhang Q, Qi HW, Hu RZ, Wang XF (2008) Mineralogy of Gebearing coal from Wulantuga super large Germanium deposit, Inner Mongolia, China. Acta Mineral Sin 4:426-432 (in Chinese with English abstract) 